Новиков А. О.,

доктор філологічних наук, професор, завідувач кафедри української мови, літератури та методики навчання Глухівський національний педагогічний університет імені Олександра Довженка

\title{
ТЕАТР МИКОЛИ САДОВСЬКОГО
}

У статті висвітлюється творчий шлях одного з найвидатніших украӥнських акторів і режисерів Миколи Садовського (Тобілевича), наголошується на тому, щэо митець входив до когорти корифеїв, які наприкінці XIX - початку XX cm. під керівництвом М. Кропивницького підняли національне театральне мистеитво на найвищий світовий щабель. Акиентується, щзо Садовський заснував перший украӥнський постійний театр у Києві, брав активну участь у розбудові західноукраӥнського театру в Галичині й Закарпатті, створив свою потужну театральну школу.

Ключові слова: корифеї, український національний театр, периий постійний театр, Галичина, Закарпаття.

В статье освещается творческий путь одного из самых выдающихся украинских актеров и режиссеров Николая Садовского (Тобилевича), отмечается, что художник входил в число корифеев, которые в коние XIX - начала XX веков под руководством М. Кропивницкого подняли национальное театральное искусство на высший мировой уровень. Акцентируется, что Садовский основал первый украинский постоянный театр в Киеве, принимал активное участие в развитии западноукраинского театра в Галиции и Закарпатье, создал свою мощную театральную школу.

Ключевые слова: корифеи, украинский национальный театр, первый постоянный театр, Галииия, Закарпатье.

The paper highlights the creative career of one of the most outstanding Ukrainian actors and directors Mykola Sadovs'ky (Tobilevych). It is noted that the artist was among the greatest coryphaeuses who being led by M. Kropyvnyts'ky raised the national theater to the highest world level at the end of XIX - the beginning of the 20th century. It is stressed that Mykola Sadovs'ky founded the first Ukrainian resident theater in Kyiv, took active part in the development of the theater in Western Ukraine, in Halychyna and Zakarpattia, created the powerful drama school.

Key words: coryphaeuses, Ukrainian national theater, first resident theater, Halychyna, Zakarpattia.

У жовтні 2017 року виповнюється 135 років від часу заснування в колишньому Єлисаветграді (тепер - Кропивницький) театру корифеїв. Одним із найталановитіших учнів i соратників M. Кропивницького - засновника уславленої трупи - був, поза сумнівом, Микола Садовський - брат I. КарпенкаКарого, П. Саксаганського й М. Садовської-Барілотті.

Свою театральну діяльність Микола Карпович Садовський (1856-1933) розпочав восени 1881 р. у Кременчуці, в російській трупі Г. Ашкаренка, куди його запросив М. Кропивницький, який працював у згаданому колективі 
режисером і провідним актором. Прикметно, що дебют Садовського збігся 3 довгоочікуваним дозволом виставляти на професійній сцені українські твори. Під керівництвом Кропивницького талановитий актор-аматор пройшов справжню театральну школу, досяг найвищих щаблів сценічної майстерності. Поруч із великим майстром був він і тоді, коли останній створив восени наступного 1882 р. знамените Театральне товариство, яке згодом стали шанобливо йменувати театром корифеїв.

Уперше на чолі трупи Садовський став 1888 р. Це був той самий зірковий театр, котрий у зимовий сезон $1886 / 87$ рр. зробив небачений фурор у Петербурзі, а згодом і в Москві. Кропивницький тоді покинув очолювану ним трупу через непорозуміння 3 провідними акторами. Під орудою Садовського колектив проіснував до кінця 1897 року, коли з нього вийшла М. Заньковецька. Щоправда, на цей час у його складі вже не було ні I. Карпенка-Карого, ні П. Саксаганського, ні М. Садовська-Барілотті, які ще 1890 р. утворили власну трупу. Саме до цієї трупи згодом і приєднався Садовський.

Активну участь взяв митець у створенні об'єднаного театру корифеїв, котрий почав свою діяльність навесні 1900 р. Колектив мав назву «Малоросійська трупа Марка Лукича Кропивницького під урядом Миколи Карповича Садовського і Опанаса Карповича Саксаганського при участі Марії Костянтинівни Заньковецької». Проіснував він близько трьох років. Останній спільний виступ найвизначніших майстрів української сцени, як і перший, відбувся в Полтаві. Сталося це 31 серпня 1903 р. - на другий день святкування урочистого відкриття пам'ятника Івану Котляревському. Власне, трупа на той час функціонувала вже не у повному своєму складі, оскільки кількома місяцями раніше (в лютому того ж 1903 р.) 3 неї вийшли Кропивницький i Заньковецька, про що повідомлялось у газеті «Одесский листок» [Одесский листок 1903]. Але комітету по влаштуванню заходів все ж таки вдалося ще раз зібрати найвизначніших українських акторів у Полтаві (за винятком М. Заньковецької, яка в цей час у складі трупи О. Суслова гастролювала в Петербурзі). Силами корифеїв була поставлена 
вічно жива «Наталка Полтавка». В ролі головної героїні виступила Л. Ліницька, виборного Макогоненка зіграв М. Кропивницький, возного Тетерваковського I. Карпенко-Карий, Терпелиху - C. Тобілевич, Петра - О. Жулінський. А Садовський у цьому спектаклі, як і завжди, виконував роль Миколи. За суфлера був Саксаганський. За словами одного із сучасників, «вистава пройшла тріумфально, кожного з виконавців глядачі зустрічали бурею оплесків, бо це ж був винятковий склад виконавиів - рідкісна подія. Цим $i$ закінчилося свято Котляревського, $і$ після цьього вже ніколи корифеї не зустрічалися у такій кількості і такому складі» [Маринич 1955:312].

Вельми яскраву сторінку залишив М. Садовський і в історії західноукраїнського театру. Варто зауважити, що на початку XX століття художній рівень театрального мистецтва в Галичині залишався досить низьким. Відтак з метою поліпшення ситуації 1904 р. керівництво товариства «Руська Бесіда» уклало контракт із Миколою Садовським, який упродовж року (до травня 1906 р.) обіймав у Руському театрі посади директора й режисера. Очоливши театр, Садовський запросив до колективу і свою незмінну сценічну партнерку та цивільну дружину М. Заньковецьку, а також давнього знайомого актора С. Паньківського, який був родом із Галичини.

Садовський запровадив на галицькій сцені нові режисерські принципи, які робили акторську гру більш реалістичною, наближеною до життя, віднайшов серед молодих акторів низку справжніх талантів, які досить скоро під його керівництвом зуміли продемонструвати високу майстерність. Серед них - Василь Юрчак, Петро Дяків, Свген Захарчук та ін. Декого з цих артистів режисер згодом запросив до свого стаціонарного театру в Києві.

Суттєво оновлений був і репертуар трупи. За Садовського на галицькій сцені виставлялися твори I. Карпенка-Карого («Бурлака», «Сто тисяч», «Батькова казка», «Наймичка», «Мартин Боруля», «Безталанна»), М. Старицького («Зимовий вечір», «Чорноморці», «Циганка Аза»), М. Кропивницького («Зайдиголова»), Є. Чирікова («Євреї») та ін. Щоправда, про історичні п'єси, котрі з великим успіхом ішли в Наддніпрянщині, як 
згадував сам М. Садовський, не могло бути й мови, оскільки «влада, від якої залежав дозвіл тієї чи іншої n’єси, була польська, а в наших історичнодраматичних творах стосунки $з$ поляками неодмінні ци неприємні» [Садовський 1956:142].

Поціновуючи режисерський хист цього визначного майстра сцени, історик галицького театру С. Чарнецький писав: «Садовський умів вивести народну драму на сцені так, щзо вона викликувала прямо вражіння дійсності, а збірні гуртові яви, як, напр[иклад] сход у II дії «Бурлаки», просто хапали за очі своєю природністю й життєвою правдою» [Чарнецький 1934:130].

Завдяки геніальній режисурі М. Садовського й неперевершеній грі М. Заньковецької Руський театр досить скоро став народною трибуною й майстер-класом для багатьох тогочасних західноукраїнських акторів.

Багато в чому визначальним і якоюсь мірою поворотним для подальшого розвитку українського сценічного мистецтва стає 1907 р. - рік початку функціонування постійного театру М. Садовського в Києві. До цього українські трупи не мали змоги подовгу виступати в одному місті, хай і великому, позаяк це потребувало постійного оновлення репертуару, що в умовах жорстокої цензури до нових українських п’єс, а також заборони виставляти перекладні твори, було практично нереальним. А головне - в ту добу на теренах Наддніпрянщини не дозволялося створювати стаціонарні українські театри. Дещо легше вирішити цю проблему стало під час першої російської революції, коли захитались устої імперії, повіяв вітер перемін і стало можливим деякі речі робити явочним порядком. Саме так і поступив Садовський.

Садовський прагнув створити трупу на кшталт Московського Художнього театру. За словами одного з учасників цих подій I. Мар'яненка, метр ставив собі за мету передусім «боротися з засміченням украӥнського репертуару мотлохом різних доморощуених драматургів, щуо писали “під Кропивницького” та “під Старищъького” $і$ культивували найпримітивнішу “горілчано-гопачну” мелодраму». Іншим пріоритетом трупи було «піднесення культури акторської гри та акторського слова. На той час це був єдиний 
украӥнський театр з такими прогресивними завданнями» [Мар'яненко 1953:145].

Садовський волів набрати у свою трупу якомога більше молоді. Чимало таких виконавців він віднайшов у Ніжині серед місцевих аматорів, якими керувала М. Заньковецька, а також у Полтаві - одному з основних осередків аматорського руху. До свого колективу митець запросив також кілька досвідчених артистів. Окрім того, до трупи увійшли М. Заньковецька (як один iз керівників), Г. Борисоглібська, О. Полянська, Ф. Левицький, І. Загорський, I. Мар'яненко, С. Паньківський, А. Герцик, О. Петляш, I. Ковалевський, Ю. Милович, Г. Березовський та ін. Згодом до них приєднався й Лесь Курбас.

Розпочав свої виступи новостворений колектив 1906 р. у Полтаві, потім поїхав із гастролями до Миргорода, Ромен, Ніжина, Житомира, Могилева, Кам'янець-Подільського. А на першому тижні Великого Посту, тобто на початку 1907 р., прибув до Києва, де Садовському на тривалий термін удалось орендувати приміщення театру «Товариства грамотності».

Репертуар трупи складався як із класичних українських творів (I. Котляревського, С. Гулака-Артемовського, М. Кропивницького, М. Старицького, I. Карпенка-Карого, I. Франка), так і п’єс сучасних авторів апологетів нової європейської драми. Йдеться передусім про драматургію Лесі Українки («Камінний господар»), В. Винниченка («Брехня»), Л. СтарицькоїЧерняхівської («Гетьман Дорошенко»). Крім того, у театрі Садовського виставлялася російська й зарубіжна класика, що для тогочасних українських труп було справжнім новаторством, оскільки раніше українською мовою їх грати було заборонено.

Серед перших постановок світових шедеврів був гоголівський «Ревізор» (1907). За словами Садовського, «ие був той іспит, що його украӥнський театр повинен був скласти перед очима всієї публіки на право стати... з високо піднесеною головою серед усіх європейських театрів» [Садовський 1956:164]. Роль Городничого виконував сам режисер. Ганни Андріївни (дружини Городничого) - О. Полянська, Марії Андріївни (їхньої доньки) - О. Петляш, 
Хлестакова - I. Мар'яненко, Бобчинського - I. Загорський, Добчинського I. Ковалевський.

Напередодні спектаклю, згадує I. Мар'яненко, серед театралів ходили розмови: «Ну, можна припустити городничого, його родину, чиновників... але щэоб Хлестаков, який приїхав з Петербурга, розмовляв украӥнською мовою - ие номер!» [Мар'яненко 1953:158].

Утім, театр успішно здав цей нелегкий іспит. Гра, що йшла у звичній реалістичній манері, була настільки високохудожньою, що глядачі забули, якою мовою виконується вистава. До того ж, на думку знавців театрального мистецтва, у постановці Садовського «було багато нового ци иіккавого» [Мар'яненко 1953:160].

1909 р., окрилена успіхом «Ревізора», трупа здійснює постановку комедії О. Островського «Доходное место», яка в перекладі М. Садовського одержала назву «Тепленьке місце». Це був другий іспит, який успішно здав колектив.

Окрім того, силами акторів Садовського були поставлені такі п'єси, як «Галька», «Сільська честь», «Євреї» Є. Чирікова, «Забавки» А. Шніцлера, опера «Катерина» (за Шевченком) М. Аркаса, музична комедія «Енеїда» (музика М. Лисенка, текст М. Садовського) та ін.

Доречно зауважити, що ціни у театрі Садовського були вельми демократичні, особливо на вранішні вистави, котрі влаштовувались у неділю та святкові дні. Кращі місця у партері на такі спектаклі коштували всього по 50 коп., не говорячи вже про галерею, куди квиток можна було придбати за п’ятак. Так митець намагався прилучити до національної культури якомога ширше коло глядачів із найбідніших верств населення - передусім студентів і гімназистів, а також робітничу молодь, що згодом дало свої позитивні результати. Вранішні вистави проходили зазвичай із аншлагом. У такий спосіб театр Садовського не тільки виховував у публіки (в тому числі майбутньої української інтелігенції) добрий естетичний смак, а й сприяв пробудженню національної самосвідомості. 
Важливою подією в культурному житті України стало святкування 15 січня 1908 року в театрі Садовського 25-річного ювілею артистичної діяльності М. Заньковецької. «Сцена була засипана квітами $i$ заставлена подарунками, - згадує I. Мар'яненко. - Безліч привітальних телеграм надійшло з усіх кінців не тільки України, але й великої Росї̈» [Мар'яненко1953:139]. Це був, по суті, підсумок творчого шляху всього нового українського театру, народження якого майже збігається 3 початком артистичної кар'єри примадонни.

У січні 1919 р., напередодні зайняття Києва більшовиками, Садовський разом з основною частиною трупи покидає місто. Спочатку театр переїхав до Вінниці, а потім до Кам'янець-Подільського, де перебував майже упродовж року. У Кам'янець-Подільському виставлялися в основному спектаклі за українською класикою. 3 нових творів репрезентована була лише вистава за п’єсою С. Васильченка «Куди вітер віє». Відносно спокійне життя акторів закінчилося на початку 1920 р., коли під натиском більшовиків армія Симона Петлюри змушена була відступити на територію Польщі. Нелегке рішення переїхати в Галичину приймає й Садовський, однак більша частина акторського колективу не підтримала свого керівника. До Станіслава (тепер Івано-Франківськ) Садовський приїхав лише 3 невеличкою групою своїх однодумців. Тут актори виступали упродовж квітня й травня, а у червні переїхали до Тернополя, де 3 великим успіхом зіграли низку творів I. Карпенка-Карого - «Мартина Борулю», «Сто тисяч», «Безталанну», «Бурлаку». Потім трупа деякий час виступала у Тарнові, а згодом попрямувала до Львова. I тут колектив розпався вже остаточно [Василько 1962:169].

Так після успішної чотирнадцятилітньої діяльності першокласний український театр припинив своє існування, а його очільник разом із драматургом С. Черкасенком і актором М. Миленком, що залишилися вірними майстру і в ці нелегкі часи, близько року змушений був жити у місті Лева без роботи. 
Знову посміхнулася фортуна Миколі Садовському на початку 1921 p., коли його несподівано запросили очолити Руський театр в Ужгороді. Запрошення надійшло від місцевого товариства «Просвіта», яке отримало від президента Чехословаччини Т. Масарика значну одноразову субсидію (250 тисяч крон) задля організації національного театру.

Варто зауважити, що постійний український театр в Ужгороді на той час уже існував. Урочисте його відкриття відбулося 15 січня 1921 р. 3 постановки драми М. Старицького «Ой не ходи, Грицю, та й на вечорниці». Виставляли у новоствореному театрі й інші широковідомі українські п’єси - «Наталку Полтавку» I. Котляревського, «Сватання на Гончарівці» Г. Квітки-Основ'яненка, «Суєту», «Хазяїна», «Наймичку», «Безталанну» I. Тобілевича (Карпенка-Карого), «Невольника» (за Шевченком) М. Кропивницького, «Украдене щастя» I. Франка, «Повернувся із Сибіру», «Лісова квітка» Л. Яновської тощо.

Ахілесовою п’ятою театру був не надто високий художній рівень вистав, що можна пояснити тим, що у складі трупи були всього два професійні актори - М. Біличенко і М. Приємська-Дніпрова. Вони ж виконували й обов'язки режисерів.

У Руському театрі Садовський обіймав дві посади - директора й режисера. Період, коли український театр у Закарпатті очолював цей визначний майстер (1921-1923рр.), поправу вважається його розквітом.

До Ужгороду Садовський прибув у липні 1921 р. Разом із ним приїхав драматург Спиридон Черкасенко, а також кілька товаришів по сцені - Микола Миленко, Валентина Іванова, Микола Кричевський. Окрім того, майстру вдалося визволити 3 табору для переміщених осіб ще кількох акторів О. Левицького, П. Чугая, М. Певного. У місцевих часописах «Руська Нива» i «Вперед» повідомлялося: «Цими днями приїхав до Ужгороду корифей руської театральної штуки Микола Садовський. <..> Розписувати про значення й славу цього чоловіка є злишне, бо це вже зробили інші люди, оиінюючи його 
працюю <..> Ми сподіваємося, щзо з його приїздом наш театр стане на европейській висоті» [Шерегій 1993:68].

За театральну справу в Закарпатті метр узявся 3 великим ентузіазмом, попри те, що створювати трупу йому довелося майже з нуля. Грали в театрі, очолюваному Садовським, переважно українську класику, зокрема, такі твори, як «Запорожець за Дунаєм» С. Гулака-Артемовського, «Назар Стодоля» Т. Шевченка, «Дай серцеві волю, заведе у неволю», «Пошились у дурні», «Вій» (за Гоголем) М. Кропивницького, «Утоплена», «Сорочинський ярмарок», «Циганка Аза», «Чорноморці», «Тарас Бульба» М. Старицького, «Катерина» (за Шевченком) М. Аркаса, «Суєта», «Хазяїн», «Сто тисяч», «Розумний і дурень», «Гандзя» I. Карпенка-Карого, «Лимерівна» П. Мирного, «Украдене щастя» I. Франка, «Про що тирса шелестіла», «Казка старого млина», «Гайдамаки», «Відьма» (за Шевченком) С. Черкасенка, «Гріх», «Натусь», «Закон» В. Винниченка, а також дещо з європейської драматургії [Василько 1962:170].

I все ж робота на чужині не надто надихала майстра, оскільки він постійно стикався 3 труднощами, які не міг здолати. I це його гнітило. Найбільша проблема полягала в тому, що значна частина мешканців Ужгорода «була або мадьярська або змадьяризована» [Василько 1962:171]. Відтак більшість глядачів не розуміли української мови, а тому не надто цікавилися спектаклями, котрі для них виконувала трупа Садовського. Аби залучити якомога більше публіки до театру, режисер улаштовував навіть безкоштовні вистави, але це мало допомагало. Театр занепадав. У пошуках заробітку актори постійно виїздили на гастролі до провінційних містечок, де переважно мешкали етнічні українці, - Берегове, Мукачів, Хуст, Солотвине, Рахів, Ясиня, Чоп, Радотин, Батів, Волосинка, Кирильгаза. Інколи вдавалося грати спектаклі навіть у столиці Чехословаччини Празі, де український репертуар користувався успіхом [Василько 1962:170]. Гарною ілюстрацією до сказаного є рядки з листа Садовського до Софії Тобілевич від 11 січня 1923 року: «Hарешті хmось про мене згадав $і$ запросили мене директорувати в Ужгороді, $і$ ось уже другий рік я бовтаюсь у цій калюжі, не бачачи вдалині ніякого просония. Роботи до чорта, 
а толку мало. 3 неуків треба було зробити акторів і сформувати театр. Тепер він вже є. Правда прийшлось додати декого з фахівцівв - тих акторів, щзо були розсипані по горах і долинах Польщу та Галичини. Але розгорнути свої крила нема де, тісно - літати не можу» [Василько 1962:169].

Такий стан справ призвів до того, що після закінчення контракту наприкінці літа 1923 р. Садовський покинув театр і переїхав до передмістя Праги з надією влаштуватися на роботу в кіностудії. Але й цим його мріям не судилось здійснитися. Потерпіли фіаско і плани організувати у Чехословаччині новий український театр, оскільки акторам М. Малиш-Федорець і С. Паньківському, яких митець мав намір запросити з України, чехословацький уряд відмовив у візах.

Неможливість займатися улюбленою театральною працею, постійний сум за рідним краєм, а також невлаштованість життя на еміграції зрештою спонукали Миколу Садовського просити дозволу повернутися в Україну. Такий дозвіл він отримав у березні 1926 р.

Микола Садовський залишив вельми помітний слід в історії українського професійного театру. Один із найблискучіших національних акторів i режисерів, він під керівництвом свого видатного вчителя й наставника Марка Кропивницького разом із М. Старицьким, I. Карпенком-Карим, П. Саксаганським, М. Заньковецькою, Г. Затиркевич-Карпинською наприкінці XIX - початку XX століть закладав основи національного професійного театру на теренах Східної України. Окрім того, він заснував перший український постійний театр у Києві, брав активну участь у розбудові західноукраїнського театру в Галичині й Закарпатті, створив свою потужну театральну школу.

\section{БІБЛІОГРАФІЯ}

Василько 1962 - Василько В. Микола Садовський та його театр / Василь Степанович Василько. - К. : Державне видавництво образотворчого мистецької і музичної літератури УРСР, 1962. - 230 с. 
Маринич 1955 - Маринич $Г$. Спогади про Марка Лукича Кропивницького / Г. Маринич // Марко Лукич Кропивницький. Збірник статей, спогадів і матеріалів. - К. : Мистецтво, 1955. - С. 301 - 314.

Мар'яненко 1953 - Мар'яненко I. О. Минуле українського театру. Зустрічі, творча праця / Іван Олександрович Мар'яненко. - К. : Мистецтво, 1953. - $184 \mathrm{c}$.

Одесский листок 1903 - Одесский листок. - 1903. - 18 февраля.

Садовський 1956 - Садовський М. К. Мої театральні згадки / М. К. Садовський. - К. : Держ. вид. образотворч. мистецтва і муз. літератури, 1956. -203 c.

Чарнецький 1934 - Чарнецький С. Нарис історії українського театру в Галичині / Степан Чарнецький. - Львів, 1934. - 260 с.

Шерегій 1993 - Шерегій Ю. Нарис історії українських театрів Закарпатської України до 1945 року / Юрій Шерегій. - Нью-Йорк - Париж Сідней - Торонто - Пряшів - Львів, 1993. - 414 с. 